\title{
Вміст циркулюючих імунних комплексів у хворих на дифузний токсичний 30б, ускладнений автоімунною офтальмопатією
}

H.M. Степypa,

Г.А. Замотаєва, Г.М. Терехова, І.П. Волинець

ДУ «Інститут ендокринології та обміну речовин ім. В.П. Комісаренка НАМН України»

Резюме. Одним із важливих показників, що характеризує стан гуморальної ланки імунної системи організму, $€$ рівень циркулюючих імунних комплексів (ЦІК). За умов надлишкового утворення, ЦІК зберігаються впродовж тривалого часу і можуть відкладатися в різних органах та судинах, де здатні ініціювати запальні процеси. Автоімунна офтальмопатія (АО) - автоімунне захворювання, яке являє собою комплексне ураження тканин орбіти, супроводжується інфільтрацією, набряком і проліферацією ретробулярної жирової клітковини, м'язів і сполучної тканини. АО може зустрічатися як самостійне захворювання, так і в сполученні з дифузним токсичним зобом (ДТЗ) або автоімунним тиреоїдитом. Припускають, що патогенетичні механізми прогресування АО можуть бути пов'язані з активацією автоімунних процесів в орбітальних тканинах на фоні високого рівня антитіл до рецепторів тиреотропного гормону (рТТГ). Метою роботи було дослідження вмісту ЦІК у хворих на ДТЗ, ускладнений АО. Матеріал і методи. Проведено визначення кількості ЦІК: у 24 хворих (19 жіноК та 5 чоловіків) із ДТЗ віком від 22 до 67 років (середнє значення - $(47,2 \pm 2,8)$ року), у 29 хворих (19 жінок та 10 чоловіків) на ДТЗ, ускладнений АО, віком від 18 до 71 року (середнє значення - $(46,1 \pm 2,5)$ року) і в 16 донорів (контрольна група) відповідного віку та статі. Результати. У хворих на ДТЗ обох груп вміст ЦІК вірогідно вищий за відповідний показник у донорів: відповідно $(92,7 \pm 6,1)$ ум. од./мл і $(113,5 \pm 6,7)$ ум. од./мл проти $(67,7 \pm 6,1)$ ум. од./мл, (р<0,05). У групі хворих на ДТ3, ускладнений АО, кількість осіб із високими значеннями ЦІК істотно більша, ніж у групі хворих на ДТ3. Так, високі значення ЦІК (100ум. од./мл і більше) виявлено в 17 із 29 (58,6\%) хворих на ДТЗ, ускладнений АО, тоді як у хворих на ДТЗ їх було 7 із 24 (29,2\%). Висновки. Збільшення продукції ЦІК у хворих на ДТЗ, ускладнений АО, імовірно, є результатом активації гуморальної ланки імунної системи та підтвердженням автоімунного ґенезу захворювання. Високий вміст ЦІК може свідчити про розлад імунного гомеостазу, зокрема, про дисфункцію ретикуло-ендотеліальної системи, яка відповідає за їх елімінацію і виведення.

Ключові слова: дифузний токсичний 30б, автоімунна офтальмопатія, циркулюючі імунні комплекси.

\footnotetext{
* Адреса для листування (Correspondence): ДУ «Інститут ендокринології та обміну речовин ім. В.П. Комісаренка НАМН України», вул. Вишгородська, 69, м. Київ, 04114,

Україна. E-mail: zdovado@ukr.net
}

() Н.M. Cтепура, Г.А. Замотаєва, Г.М. Терехова, І.П. Волинець 
Найпоширенішим автоімунним захворюванням щитоподібної залози (ЩЗ) є ДТЗ (хвороба Грейвса), яка супроводжується продукцією антитіл до рТТГ, що чинять постійну стимулюючу дію на Щ3 [1-5]. Це призводить до збільшення маси і гіперфункції Щ3, i, як наслідок, до підвищення рівня тиреоїдних гормонів. За даними різних авторів, у 5-20\% хворих на ДТЗ розвивається АО [6]. AO (злоякісний екзофтальм, ендокринна офтальмопатія, тиреотоксична офтальмопатія, офтальмопатія Грейвса) - автоімунне захворювання, яке проявляється комплексним ураженням м'яких тканин орбіти та характеризується інфільтрацією, набряком і проліферацією ретробульбарної жирової клітковини, м'язів і сполучної тканини. АО може бути як самостійним захворюванням, так і в сполученні з ДТЗ або автоімунним тиреоїдитом [7]. Зв’язок між ДТЗ та АО не викликає сумніву, оскільки обидва патологічні процеси мають автоімунну природу $[1,3]$. За дії різних ендо- та екзогенних чинників (інфекція, стрес, куріння та ін.) у людей із генетичною схильністю запускаються автоімунні реакції як проти автоантигенів ЩЗ (у випадку ДТЗ), так і проти структур орбіти з наступним ураженням тканин ока (у випадку АO) [2]. Близько 70\% генів, пов'язаних з автоімунними захворюваннями ЩЗ, залучені також у регуляцію функції Т-клітин [1].

Розповсюдженість АО серед населення досить висока - кожного року це захворювання діагностують приблизно в 1 на 10000 осіб, частіше в жінок. Вкрай тяжкий перебіг АО розвивається приблизно у $9 \%$ випадків і призводить до різкого погіршення зору внаслідок розвитку оптичної нейропатії [1].

Незважаючи на велику кількість досліджень з проблеми діагностики та лікування ДТЗ і АО, ще й досі недостатньо вивченими залишаються патогенез цього захворювання й ефективність різних методів його лікування [7].

Одним із важливих показників, що характеризує стан гуморальної імунної відповіді організму, є рівень ЦІК, які утворюються під час безпосереднього з'єднання антигенів (як екзогенних, так i ендогенних) 3 антитілами. В організмі людини існує ціла низка імунорегуляторних механізмів, які підтримують фізіологічний рівень ЦІК. За умов надлишкового утворення, ЦІК зберігаються впродовж тривалого часу і можуть відкладатися в різних органах та судинах, де здатні ініціювати запальні процеси.

У науковій літературі представлені результати досліджень рівня ЦІК у хворих на ДТЗ залежно від методів лікування [8-10]. Проте, даних щодо вмісту ЦІК у хворих на ДТЗ, ускладнений АО, нами не виявлено.

Метою нашої роботи було визначення та порівняння вмісту ЦІК у хворих на ДТЗ і хворих на ДТЗ, ускладнений АО.

\section{Матеріал і методи}

Проведено визначення рівня ЦІК у 24 хворих на ДТ3 (перша група), у 29 хворих на ДТЗ, ускладнений АО (друга група) і в 16 практично здорових донорів.

Характеристика хворих представлена в таблиці 1.

Рівень ЦІК у сироватці крові хворих визначали методом преципітації поліетиленгліколем із молекулярною масою 6000 («Serva», Hiмеччина) з наступним вимірюванням оптичної щільності досліджуваних зразків на спектрофотометрі СФ-46 («ЛОМО», Росія) за довжини хвилі 450 нм [11]. Вміст ЦІК представляли в умовних одиницях на мл (ум. од./мл) $\left(\mathrm{E}_{450} \times 10^{3}\right)$.

Статистичну обробку даних проводили методом варіаційної статистики з обчисленням t-критерію Стьюдента. Різницю вважали вірогідною при $\mathrm{p}<0,05$.

До початку роботи було отримано позитивне рішення Комісії з медичної етики ДУ

Таблиця 1. Характеристика хворих

Table 1. Characteristics of patients

\begin{tabular}{|c|c|c|c|}
\hline $\begin{array}{l}\text { Група } \\
\text { Group }\end{array}$ & $\begin{array}{l}\text { Кількість } \\
\text { Quantity }\end{array}$ & $\begin{array}{l}\text { Вік } \\
\text { Age }\end{array}$ & $\begin{array}{l}\text { Стать } \\
\text { (ж/ч) } \\
\operatorname{Sex}(f / m)\end{array}$ \\
\hline $\begin{array}{l}\text { Здорові донори } \\
\text { Healthy donors }\end{array}$ & 16 & $\begin{array}{l}37,6 \pm 3,2 \\
31-55\end{array}$ & $10 / 6$ \\
\hline $\begin{array}{l}\text { Дифузний токсичний зоб } \\
\text { Diffuse toxic goiter }\end{array}$ & 24 & $\begin{array}{l}47,2 \pm 2,8 \\
22-67\end{array}$ & $19 / 5$ \\
\hline $\begin{array}{l}\text { Дифузний токсичний зоб, } \\
\text { ускладнений автоімунною } \\
\text { офтальмопатією } \\
\text { Diffuse toxic goiter } \\
\text { complicated by autoimmune } \\
\text { ophtalmopathy }\end{array}$ & 29 & $\begin{array}{l}46,1 \pm 2,5 \\
18-71\end{array}$ & 19/10 \\
\hline
\end{tabular}


«Інститут ендокринології та обміну речовин ім. В.П. Комісаренка НАМН України» і інформовані згоді від усіх обстежених.

\section{Результати та обговорення}

Результати визначення кількості ЦІК у хворих на ДТЗ і хворих на ДТЗ, ускладнений АО, представлені в таблиці 2.

Як видно з результатів, у хворих на ДТЗ і хворих на ДТЗ, ускладнений АО, вміст ЦІК достовірно більший за відповідний показник у здорових донорів у 1,4 і 1,7 раза відповідно (табл. 2). Вміст ЦІК у хворих на ДТЗ, ускладнений АО, був на 22,4\% більшим за відповідний показник у хворих на ДТЗ.

Показники ЦІК, вищі за референтні значення (45-75 ум. од./мл), виявлені у 18 осіб із 24 хворих на ДТЗ і у 25 осіб із 29 хворих на ДТЗ, ускладнений АО, тобто відсоток хворих із підвищеним вмістом ЦІК був майже однаковим (75\% і 86\% відповідно).

Високі значення ЦІК (100 ум. од./мл і більше) частіше виявлялися у хворих на ДТЗ, ускладнений $\mathrm{AO},-$ у 17 із 29 осіб (58,6\%), тоді

Таблиця 2. Рівень ЦІК хворих на ДТЗ і у хворих на ДТЗ, ускладнений $\mathrm{AO}$ (ум. од./мл) $\left(\mathrm{E}_{450} \times 10^{3}\right)$

Table 2. The level of circulating immune complexes in patients with diffuse toxic goiter and in patients with diffuse toxic goiter complicated by autoimmune ophthalmopathy (conventional units $/ \mathrm{ml})\left(\mathrm{E}_{450} \times 10^{3}\right)$

\begin{tabular}{|c|c|c|c|}
\hline \multirow[t]{2}{*}{$\begin{array}{l}\text { Показник } \\
\text { Indication }\end{array}$} & \multicolumn{3}{|l|}{$\begin{array}{l}\text { Група } \\
\text { Group }\end{array}$} \\
\hline & $\begin{array}{l}\text { Здорові } \\
\text { донори } \\
\text { Healthy } \\
\text { donors } \\
(n=16)\end{array}$ & $\begin{array}{l}\text { Дифузний } \\
\text { токсичний } \\
\text { зоб } \\
\text { Diffuse toxic } \\
\text { goiter } \\
\text { (n=24) }\end{array}$ & $\begin{array}{l}\text { Дифузний } \\
\text { токсичний зоб, } \\
\text { ускладнений } \\
\text { автоімунною } \\
\text { офтальмопатією } \\
\text { Diffuse toxic goiter } \\
\text { complicated by } \\
\text { autoimmune } \\
\text { ophtalmopathy } \\
\text { (n=29) }\end{array}$ \\
\hline 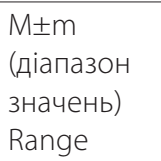 & $\begin{array}{l}67,7 \pm 6,1 \\
(47-78)\end{array}$ & $\begin{array}{l}92,7 \pm 6,1 \\
(55-152)\end{array}$ & $\begin{array}{l}113,5 \pm 6,7 \\
(61-196)\end{array}$ \\
\hline $\begin{array}{l}p_{1} \\
p_{2}\end{array}$ & & $<0,05$ & $\begin{array}{l}<0,05 \\
<0,05\end{array}$ \\
\hline
\end{tabular}

Примітка: $p_{1}$ - вірогідність відносно групи здорових донорів; $p_{2}$ - вірогідність відносно групи хворих на ДТЗ.

Note: $p_{1}$ - significant differences in the healthy donors;

$p_{2}$ - significant differences in group of patients with diffuse toxic goiter.

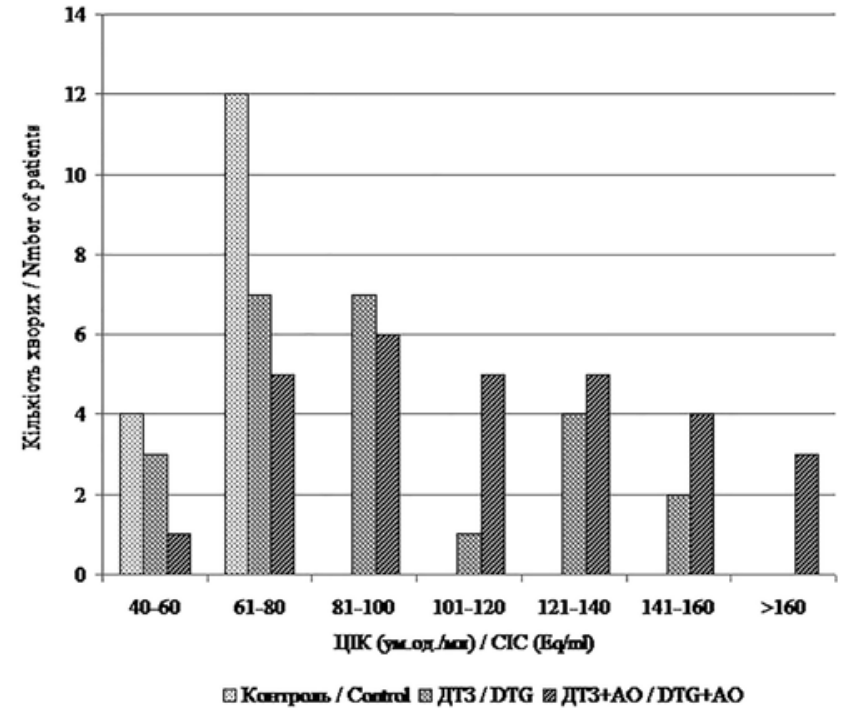

Рис. Розподіл хворих на ДТЗ і хворих на ДТЗ, ускладнений АО, за рівнем ЦІК

Fig. Distribution of patients with DTG and patients with DTG complicated by AO, according to the level of the CIC.

як у хворих на ДТЗ такі показники були в 7 із 24 осіб (29,2\%). Розподіл кількості хворих залежно від вмісту ЦІК у сироватці крові представлено на рисунку.

Відомо, що високі рівні ЦІК блокують проліферацію В-лімфоцитів (через зв'язок IK 3 антигеном і Fc-рецептором, маскування і захист антигену), пригнічують функцію клітин-ефекторів (зокрема, природних клітинкілерів) і перешкоджають взаємодії клітин в імунній відповіді [12, 13]. Високий рівень ЦІК (особливо тих, що містять імуноглобуліни класу G) стимулює супресорну активність Т-клітин. Таким чином, ЦІК є патогенетичним чинником розвитку запальних і автоімунних процесів, судинних уражень.

Високий рівень комплексів антиген-антитіло, виявлений нами у хворих на ДТЗ і хворих на ДТЗ, ускладнений АО, імовірно, є результатом активації гуморальної ланки імунітету та підтвердженням автоімунного генезу захворювання. Високий рівень ЦІК у цих хворих може свідчити про розлад імунного гомеостазу, зокрема, дисфункцію ретикуло-ендотеліальної системи, що відповідає за виведення ЦІК із кров'яного русла.

\section{Висновки}

1. У хворих на ДТЗ і хворих на ДТЗ, ускладнений АО, вміст ЦІК вірогідно вищий за 
показники здорових донорів у 1,4 і 1,7 раза відповідно.

2. При приєднанні АО у хворих на ДТЗ кількість ЦІК зростала на 22,4\%.

3. Відсоток хворих на ДТЗ і хворих на дТЗ, ускладнений $\mathrm{AO}, 3$ підвищеним вмістом ЦІК був майже однаковим (75\% і 86\% відповідно).

4. Високий рівень ЦІК за даного патологічного процесу, імовірно, є результатом активації гуморальної ланки імунітету та може свідчити про дисфункцію ретикуло-ендотеліальної системи, що відповідає за їх виведення.

\section{Список використаної літератури}

1. Smith TJ, Hegedüs L. Graves' Disease. N Engl J Med. 2016 Oct 20;375(16):1552-1565.

2. Antonelli A, Ferrari SM, Ragusa F, Elia G, Paparo SR, Ruffilli I, et al. Graves' disease: Epidemiology, genetic and environmental risk factors and viruses. Best Pract Res Clin Endocrinol Metab. 2020 Jan;34(1):101387.

3. Morshed SA, Latif R, Davies TF. Delineating the autoimmune mechanisms in Graves' disease. Immunol Res. 2012 Dec;54(13):191-203.

4. Antonelli A, Ferrari SM, Corrado A, Di Domenicantonio A Fallahi P. Autoimmune thyroid disorders. Autoimmun Rev. 2015 Feb;14(2):174-80.

5. Паньків ВІ. Захворювання щитоподібної залози: навчальний посібник. Чернівці: БДМА: 2003; 258 с. (Pankiv VI. Thyroid disease: a textbook. Chernivtsi: BSMA: 2003; 258 p.).

6. Novaes P, Diniz Grisolia AB, Smith TJ. Update on thyroidassociated Ophthalmopathy with a special emphasis on the ocular surface. Clin Diabetes Endocrinol. 2016 Nov 16;2:19.

7. Олійник ВА, Терехова ГМ, Булдигіна ЮВ, Федько ТВ, Клочкова ВМ, Раков ОВ, Лисова ЗГ. Лікування глюкокортикоїдами автоімунної офтальмопатії у хворих на дифузний токсичний зоб. Ендокринологія. 2017;22(2):108-14. (Olyinyk VA, Terekhova GM, Buldygina YV, Fedko TV, Klochkova VM, Rakov OV, Lysova ZG. Treatment of autoimmune ophthalmopathy in patients with diffuse toxic goiter byglucocorticoids. Endokrynologia. 2017;22(2):108-14).

8. Геворкян АГ, Цогоев АС, Болиева ЛЗ. Сравнительная характеристика показателей иммунного статуса больных диффузным токсическим зобом и аутоиммунным тиреоидитом. Вестник новых медицинских технологий. 2007; XIY(3):155-6. (Gevorkyan AG, Tsogoyev AS, Boliyeva LZ. Comparative characteristics of the immune status of patients with diffuse toxic goiter and autoimmune thyroiditis. Vestnik novykh medizinskikh tekhnologii. 2007; XIY(3):155-6).

9. Ляшенко ЕА. Нарушения гуморального иммунитета у больных с аутоиммунными заболеваниями щитовидной железы и их коррекция полибиолоном. Український медичний альманах. 2013;16(3):98-100. (Ljashenko EA. Violations of humoral immunity in patients with autoimmune thyroid diseases and their correction polibiolonom. Ukrainskyi medychnyi almanakh. 2013;16(3):98-100).

10. Шагарова СГ. К проблеме иммунопатогенеза аутоиммунных заболеваний щитовидной железы. Сибирский медицинский журнал (Иркутск). 2011;100(1):42-5. (Shagarova SG. About the problem of the immunopathogenesis of thyroid gland autoimmune diseases. Sibirskii medicinskii jurnal (Irkutsk). 2011;100(1):42-5)

11. Hasková V, Kaslik J, Riha I, Matl I, Rovenský J. Simple method of circulating immune complex detection in human sera by polyethylene glycol precipitation. Z Immunitatsforsch Immunobiol. 1978 Jun;154(4):399-406.
12. Ройт А, Бростофф Дж, Мейл Д. Иммунология. 2-е изд. Пер. с англ. Москва: Мир; 2000. 592 с. (Roitt I, Brostoff J, Male D. Immunology. 2nd ed. Translated from English. Moskva: Mir; 2000. 592 p.).

13. Daniel V, Süsal C, Weimer R, Zimmermann R, Huth-Kühne A Opelz G. Association of immune complexes and plasma viral load with $\mathrm{CD} 4+$ cell depletion, CD8+ DR + and $\mathrm{CD} 16+$ cell counts in HIV+ hemophilia patients. Implications for the immunopathogenesis of HIV-induced CD4+ lymphocyte depletion. Immunol Lett. 2001 Mar 1;76(2):69-78.

(Надійшла до редакиії 15.09.2020 р.)

\section{Содержание циркулирующих иммунных комплексов у больных диффузным токсическим зобом, осложненным аутоиммунной офтальмопатией}

\section{Н.Н. Степура, Г.А. Замотаева, Г.Н. Терехова, И.П. Волынец}

ГУ «Институт эндокринологии и обмена веществ им. В.П. Комиссаренко НАМН Украины»

Резюме. Одним из важных показателей, характеризующих состояние гуморального звена иммунной системы организма, является уровень циркулирующих иммунных комплексов (ЦИК). При условии избыточного образования, ЦИК сохраняются длительное время и могут откладываться в различных органах и сосудах, инициируя воспалительные процессы. Аутоиммунная офтальмопатия (АО) - аутоиммунное заболевание, которое представляет собой комплексное поражение тканей орбиты, сопровождается инфильтрацией, отеком и пролиферацией ретробульбарной жировой клетчатки, мышц и соединительной ткани. АО может встречаться как самостоятельное заболевание, так и в сочетании с диффузным токсическим зобом (ДТз) или аутоиммунным тиреоидитом. Предполагается, что патогенетические механизмы прогрессирования AО могут быть связаны с активацией аутоиммунных процессов в орбитальных тканях на фоне высокого уровня антител к рецепторам тиреотропного гормона. Целью работы было исследование содержания ЦИК у больных с ДТЗ, осложненным АО. Материал

и методы. Проведено определение количества ЦИК: у 24 больных (19 женщин и 5 мужчин) с ДТ3 в возрасте от 22 до 67 лет (среднее значение - $(47,2 \pm 2,8)$ лет), у 29 больных (19 женщин и 10 мужчин) с ДТ3, осложненным АО, в возрасте от 18 до 71 года (среднее значение - $(46,1 \pm 2,5)$ лет) и у 16 доноров (контрольная группа) соответствующего возраста и пола. Результаты. У больных с ДТЗ обеих груп содержание ЦИК достоверно выше соответствующего показателя у доноров: соответственно $(92,7 \pm 6,1)$ усл. ед./мл и $(113,5 \pm 6,7)$ усл. ед./мл против $(67,7 \pm 6,1)$ усл. ед./мл, ( $p<0,05)$. В группе больных с ДТ3, осложненным АО, количество лиц с высокими значениями ЦИК было существенно больше, чем в группе больных с ДТ3. Так, высокие значения ЦИК (100 усл. ед./мл и более) выявлено у 17 из 29 (58,6\%) больных с ДТ3, осложненным АО, в то время как у больных с ДТ3 их было 7 из 24 (29,2\%). Выводы. Увеличенная продукция ЦИК у больных с ДТЗ, осложненным 
АО, вероятно, является результатом активации гуморального звена иммунной системы и подтверждением аутоиммунного генеза заболевания. Высокое содержание ЦИК может свидетельствовать о расстройстве иммунного гомеостаза, в частности, о дисфункции ретикуло-эндотелиальной системы, которая отвечает за их элими нацию и выведение.

Ключевые слова: диффузный токсический зоб, аутоиммунная офтальмопатия, циркулирующие иммунные комплексы.

\section{Circulating immune complexes content in patients with diffuse toxic goiter complicated by autoimmune ophthalmopathy}

\section{N.N. Stepura, G.A. Zamotayeva, G.N. Terekhova, I.P. Volynets}

SI « V.P. Komisarenko Institute of Endocrinology and Metabolism of the National Academy of Medical Sciences of Ukraine»

\begin{abstract}
The level of circulating immune complexes $(\mathrm{CIC})$ is one of the important indicators characterizing the state of the body's humoral immune response. Under the condition of excessive formation, $\mathrm{CIC}$ remain in the circulation for a long time, and can be deposited in various organs and vessels, initiating inflammatory processes. Autoimmune ophthalmopathy $(\mathrm{AO})$ is an autoimmune disease that is a complex lesion of the orbit tissues, accompanied by infiltration, edema and proliferation of retrobular adipose tissue, muscles, and connective tissue. AO can be occured as an independent disease, and in combination with diffuse toxic goiter (DTG) or autoimmune thyroiditis. It is assumed that the pathogenetic mechanisms of the progression of autoimmune ophthalmopathy may be associated with the activation of autoimmune processes in orbital tissues against the background of a high level of TSH receptor antibodies (TRAbs). The aim was to study the content of CICs in patients with DTG complicated by autoimmune ophthalmopathy. Material and methods. $\mathrm{CIC}$ were determined in 24 patients with DTG, including 19 women and 5 men aged 22 to 67 years (mean value $(47.2 \pm 2.8$ ), and in 29 patients with DTG (19 women and 10 men) complicated by $\mathrm{AO}$ at the age from 18 till 71 years (mean value $46.1 \pm 2.5$. The control group consisted of 16 donors of the corresponding age and gender. Results. In
\end{abstract}

patients with DTG of both groups the CIC content is significantly higher than the indicators of the control group: (92.7 \pm 6.1 conventional units) and (113.5 \pm 6.7 conventional units) versus $(67.7 \pm 6.1$ conventional units), $(p<0.05)$, respectively. In the group of patients with DTG complicated by $\mathrm{AO}$, the number of patients with high $\mathrm{CIC}$ values was significantly higher than in the group of patients with DTG. High CIC values (100 conventional units/ml and more) were found in 17 out of 29 (58.6\%) patients with DTG, complicated by AO, while there were 7 out of 24 (29.2\%) in patients with DTG. Conclusions. The increased CIC production in patients with DTG complicated by AO is probably the result of activation of the humoral immunity and confirmation of the genesis of the autoimmune disease. In addition, a high content of CIC may indicate a dysfunction in the genesis of immune disorders in particular, about dysfunction of the reticuloendothelial system, which is responsible for their elimination and excretion.

Keywords: diffuse toxic goiter, autoimmune ophthalmopathy, circulating immune complexes.

Для цитування: Степура НM, Замотаєва ГА, Терехова ГМ, Волинець ІП. Вміст циркулюючих імунних комплексів у хворих на дифузний токсичний 30б, ускладнений автоімунною офтальмопатією. Ендокринологія. 2020;25(4):305-309. DOI: 10.31793/16801466.2020.25-4.305.

Відомості про авторів: Наталія Миколаївна Степура, канд. біол. наук, старш. наук. співроб., ORCID: 0000-0002-9354-3762; Галина Анатоліївна Замотаєва, канд. біол. наук, старш. наук. співроб., ORCID: 0000-0002-2298-0105; Галина Миколаївна Терехова, канд. мед. наук, старш. наук. співроб., ORCID: 0000-0002-3195-446X; Ірина Петрівна Волинець, лікар-радіолог ORCID: 0000-0003-0072-9099.

Особистий внесок: Н.М. Степура, І.П. Волинець, Г.М. Терехова проведення досліджень, аналіз результатів, підготовка та написання статті, Г.А. Замотаєва — аналіз проблеми і результатів, переклад резюме, редагування та оформлення статті.

Фінансування: стаття підготовлена в рамках бюджетного фінансування Національної академії медичних наук України.

Декларація з етики: автори задекларували відсутність конфлікту інтересів і фінансових зобов'язань. 